\title{
EXPERIMENTALWORKS
}

UDC 576.322, 577.22

doi: https://doi.org/10.15407/ubj90.04.025

\section{THE P60-S6K1 ISOFORM OF RIBOSOMAL PROTEIN S6 KINASE 1 IS A PRODUCT OF ALTERNATIVE mRNA TRANSLATION}

\author{
I. V. ZAIETS, A. S. SIVCHENKO, A. I. KHORUZHENKO, \\ L. O. SAVINSKA, V. V. FILONENKO \\ Institute of Molecular Biology and Genetics, National Academy \\ of Sciences of Ukraine, Kyiv; \\ e-mail: filonenko@imbg.org.ua
}

\begin{abstract}
Ribosomal protein S6 kinase 1 (S6K1) is a well-known downstream effector of mTORC1 (mechanistic target of rapamycin complex 1) participating primarily in the regulation of cell growth and metabolism. Deregulation of mTOR/S6K1 signaling can promote numerous human pathologies, including cancer, neurodegeneration, cardiovascular disease, and metabolic disorders. As existing data suggest, the S6K1 gene encodes several protein isoforms, including $p 85-S 6 K 1, p 70-S 6 K 1$, and p60-S6K1. The two of these isoforms, $p 85-S 6 K 1$ and $p 70-S 6 K 1$, were extensively studied to date. The origin and functional significance of the p60-S6K1 isoform remains a mystery, however, it was suggested that the isoform could be a product of alternative S6K1 mRNA translation. Herein we report the generation of HEK-293 cells exclusively expressing p60-S6K1 as a result of CRISPR/Cas9-mediated inactivation of $p 85 / p 70-S 6 K 1$ translation. Moreover, the generated modified cells displayed the elevated level of p60-S6K1 expression compared to that in wild-type HEK-293 cells. Our data confirm an assumption that p60-S6K1 is alternatively translated, most probably, from the common for both $p 70$ - and p85-S6K1 mRNA transcript and reveal a link between p60-S6K1 expression and such cellular processes as cell proliferation and motility. In addition, our findings indicate that the p60-S6K1 isoform of S6K1 may undergo a mode of regulation distinct from $p 70$ - and p85-S6K1 due to the absence of mTOR-regulated p60-S6K1 phosphorylation at T389 that is important for S6K1 activation.
\end{abstract}

Keywords: CRISPR/Cas9 technology, p60-S6 kinase 1 (p60-S6K1) isoform, Akt/mTOR/S6K1 signaling pathway.

$\mathrm{D}$ iverse environmental signals from growth factors, hormones, energy and nutrients converge at mammalian target of rapamycin complex 1 (mTORC1) signaling enabling cells to promote anabolic and inhibit catabolic processes $[1,2]$. Aberrant mTORC1-dependent signaling can contribute to cancer, diabetes, obesity and several other pathological states [3].

A number of downstream effects of mTORC1, including protein biosynthesis, cell growth, proliferation and survival $[4,5]$ are mediated via ribosomal protein S6 kinase 1 (S6K1), a well-studied mTORC1 substrate.
The S6K1 gene (RPS6KB1) was shown to encode two well-known S6K1 isoforms, p85-S6K1 and p70-S6K1, that differ only by the presence of the Nterminal 23 a.a. extension in p85-S6K1 due to the use of alternative (the first and second ATG) translational start sites [6]. Recently, it has been discovered that the splicing factor SF2/ASF promotes the expression of the oncogenic and the only known S6K1 splice variant termed p31-S6K1 or S6K1-isoform 2 that is truncated from the C-terminus [7]. A mechanism underlying oncogenic properties of p31-S6K1 is unclear but it seems to be kinase-independent, since the kinase domain of the given isoform is severely truncated.

(C) 2018 Zaiets I. V. et al. This is an open-access article distributed under the terms of the Creative Commons Attribution License, which permits unrestricted use, distribution, and reproduction in any medium, provided the original author and source are credited. 
According to the existing data, the usage of an alternative translation start site (the third ATG) may yield the expression of the additional putative S6K1 isoform [8], p60-S6K1, which is 30 a.a. and 53 a.a. shorter than p70-S6K1 and p85-S6K1, respectively, and has an intact kinase domain. However, there is no direct evidence supporting this assumption and one cannot exclude the possibility of p60-S6K1 generation via limited proteolytic degradation of the $\mathrm{N}$-terminal kinase region.

Numerous experimental data suggest the implication of the S6K1 N-terminal domain in the regulation of kinase activity [reviewed in 2]. Thus, deletion of N-terminal 53 amino acids in p85-S6K1 (as in the p60-S6K1 isoform) inhibits S6K1 activity and phosphorylation similar to the action of mTOR inhibitor rapamycin [9]. Surprisingly, deletion of additional 24 a.a. ( $\Delta 77$ a.a.) has rescued the negative effect of 53 a.a. deletion causing generation of a constitutively active S6K1 form [10]. Later on, a short sequence at the N-terminus of p70-S6K1 was identified to be important for mTOR-mediated S6K1 activation and was termed the TOS (mTOR signaling) motif. Deletion of the TOS motif or its mutagenic inactivation abolishes S6K1 kinase activity indicating the critical regulatory function of the N-terminus [11]. In addition, we have demonstrated that CK2-mediated phosphorylation of Ser-17 located within the p70S6K1 N-terminus is implicated in the regulation of kinase nuclear export that could be a mode of its nuclear substrates regulation [12].

The above data indicate that the p60-S6K1 isoform should have regulation and functional activity in a cell different from that of p70-S6K1 and p85$\mathrm{S6K} 1$, however, this aspect of p60-S6K1 is poorly investigated.

To date, several studies indicate an important role for S6K1 in cancer initiation and progression. Overexpression of the S6K1 gene and deregulated S6K1 signaling have been found in different malignancies, including breast, prostate, thyroid, brain and gastric cancers [13-21] that according to multiple studies correlate with poor prognosis of disease [14, 20-22]. However, implication of different S6K1 isoforms in carcinogenesis is poorly understood.

The aim of the present study was, firstly, to verify the hypothesis that p60-S6K1 is alternatively translated from the common for p70-S6K1 and p85S6K1 template and, secondly, to evaluate the functional activity of the p60-S6K1 isoform in a cell.

For this purpose we applied the CRISPR/Cas9 technology to generate HEK-293 cell lines with dis- rupted expression of p70-S6K1 and p85-S6K1 isoforms by editing the DNA sequence between the second and hypothetical third alternative start of p60-S6K1 isoform translation. According to our data, inactivation of translation start sites for p70S6K1 and p85-S6K1, located upstream to the third ATG, completely suppressed the expression of these isoforms, but had no inhibitory effect on expression of p60-S6K1 supporting an existing assumption that p60-S6K1 is alternatively translated from the third ATG.

Upon the generation of $\mathrm{p} 85-/ \mathrm{p} 70^{-} / \mathrm{p} 60^{+} \mathrm{HEK}-293$ cells, we elucidated proliferative and migratory properties of the cells comparing them with the p85\% p70/p60-HEK-293 cells generated previously [23]. A state of S6K1 substrates phosphorylation has also been assessed. A phenotype of HEK-293 expressing only p60-S6K1 isoform confers both proliferative and migratory advantage over the S6K1 null cells, despite a decreased rate of cell proliferation and migration compared to the parental HEK-293 cells. The given cell model and the data obtained in this study can facilitate unraveling the p60-S6K1 cellular regulation and function.

\section{Materials and Methods}

CRISPR gRNA design and cloning. To create anti-S6K1 gRNA the http://crispr.mit.edu/ [24] web server was utilized. This gRNA design web tool allows for an off-target search over the genome and calculates quality scores for each gRNA selected. The higher score certain gRNA has the more specifically it binds to a target. The pair of oligonucleotides for targeting the region of the S6K1 gene with a highest score is:

Top gRNA strand: 5'-CACCGTCCTCAGAGCCCGCGTCCTC-3'

Bottom gRNA strand: 5'-AAACGAGGACGCGGGCTCTGAGGAC-3'

Underlined sequences correspond to the target S6K1 gene sequence, and unstressed sequences correspond to the Esp3I restriction site. The complementary oligonucleotide duplexes were ligated with the pSpCas9(BB)-2A-Puro (PX459) V2.0 cloning vector driven by the U6 promoter. This vector is dedicated for gRNA cloning and encodes the human Cas9 endonuclease necessary for gRNA functioning. The Esp3I restriction site was used for anti-S6K1 gRNA insertion. PCR amplification and DNA sequencing (Applied Biosystems ${ }^{\mathrm{TM}} 3130$ DNA Analyzer) were used to prove that gRNA was inserted 
into the indicated vector. The U6 primer was applied as a forward one (5'-GAGGGCCTATTTCCCATGATTCC-3') and the oligonucleotide conforming to the bottom gRNA strand was employed as a reverse primer (5'-AAACGAGGACGCGGGCTCTGAGGAC-3').

Cell culture and transfection. The human embryonic kidney cell line HEK-293 was maintained in Dulbecco's Modified Eagle's Medium (DMEM) supplemented with $10 \%$ fetal bovine serum (FBS) [GIB$\mathrm{CO}], 100 \mathrm{units} / \mathrm{ml}$ penicillin, and $100 \mu \mathrm{g} / \mathrm{ml}$ streptomycin, and cultured at $37^{\circ} \mathrm{C}\left(5 \% \mathrm{CO}_{2}\right)$. Derivatives of HEK-293 cells expressing Cas9 and anti-S6K1 gRNA were developed by transfecting the HEK-293 cells [jetPEI transfection reagent (Polyplus-transfection $\left.\left.{ }^{\circledR} \mathrm{SA}\right)\right]$ for $24 \mathrm{~h}$ with the pSpCas9(BB)-2APuro (PX459) V2.0 vector encoding corresponding gRNA. Selection was carried out by the incubation of the transfected HEK-293 cells in puromycin containing media $(4 \mu \mathrm{g} / \mathrm{ml})$ for $24 \mathrm{~h}$. Single clones were isolated for further analysis.

Antibodies. Rabbit polyclonal antibodies and mouse monoclonal antibodies (C3/10) specific to the C-terminal region of S6K1 (amino acids 453525 in p85-S6K1) were generated as described in $[25,26]$. The $\beta$-actin antibody was obtained from Sigma-Aldrich. Anti-phospho-p70-S6K1 (Thr389), anti-phospho-rpS6 (Ser235/236), anti-phospho-rpS6 (Ser240/244), anti-phospho-eEF-2K (Ser366), and anti-phospho-Akt (Ser473) were obtained from Cell Signaling Technology. Anti-mouse and anti-rabbit antibodies coupled to horseradish peroxidase were from Jackson ImmunoResearch.

Cell lysis, immunoprecipitation and Western blotting. Cells were lysed on ice for $30 \mathrm{~min}$ in $20 \mathrm{mM}$ Tris-HCl, pH 7.5, $150 \mathrm{mM} \mathrm{NaCl}, 1 \mathrm{mM}$ EDTA, 1 mM EGTA, $0.5 \%$ Triton X-100, supplemented with a Complete EDTA-free protease inhibitor cocktail tablet (Roche) and phosphatase inhibitors (SigmaAldrich). Lysates were cleared by centrifugation at $12,000 \mathrm{~g}$ for $15 \mathrm{~min}$ at $4{ }^{\circ} \mathrm{C}$. Bradford assay was used to calculate protein concentrations. The precipitating antibodies were incubated with protein-A-agarose (Pierce) for $1 \mathrm{~h}$ followed by incubation with a cell lysate overnight at $4{ }^{\circ} \mathrm{C}$ with shaking. Immunoprecipitates were washed three times with a lysis buffer before the immune complexes were eluted from beads with Laemmli loading buffer. Wholecell lysates and immunoprecipitates were resolved by $10 \%$ SDS-PAGE. The proteins were transferred to a polyvinylidene difluoride (PVDF) membrane.
The membrane was blocked with $5 \%$ low-fat milk in TBS-T (50 mM Tris-HCl, pH 7.4, $150 \mathrm{mM} \mathrm{NaCl}$ and $0.1 \%$ Tween-20) and after that it was incubated with the indicated primary antibodies used according to the manufacturer's instructions. Antibodies against the S6K1 C-terminus were diluted $1: 2500(0.4 \mu \mathrm{g} /$ $\mathrm{ml}$ ) and incubated overnight at $4{ }^{\circ} \mathrm{C}$. Afterwards, secondary antibodies linked to horseradish peroxidase were diluted $1: 10000$ and incubated at room temperature for 1 hour. The proteins of interest were revealed using enhanced chemiluminescence reagent (GE Healthcare).

Immunofluorescence. The wild-type HEK-293 and $\mathrm{p} 85 \% \mathrm{p} 70^{-} / \mathrm{p} 60^{+} \mathrm{HEK}-293$ cells were plated on glass coverslips in a 24-well plate and incubated to reach $70-80 \%$ confluence. Afterwards, cells were fixed with $10 \%$ neutral buffered formalin for $15 \mathrm{~min}$ and then washed three times with PBS. After fixation, $0.2 \%$ Triton X-100 in $100 \mu \mathrm{l}$ of PBS was added to permeabilize the cells. To block non-specific staining the coverslips were incubated in a blocking solution (10\% fetal calf serum in PBS) for $30 \mathrm{~min}$ at $37^{\circ} \mathrm{C}$. The cells were immunostained with rabbit polyclonal antibodies against the S6K1 C-terminus [25] diluted $1: 100$ in PBS overnight at $4{ }^{\circ} \mathrm{C}$, followed by incubation with secondary FITC-labeled anti-rabbit antibodies (Jackson ImmunoResearch) diluted $1: 400$ in PBS. Thereafter, the samples were mounted on microscope slides using the Mowiol medium (Sigma) containing 2.5\% DABCO (Sigma) and $0.5 \mathrm{mg} / \mathrm{ml}$ of DAPI (Pierce). Images were taken using the Zeiss LSM 510 META microscope (Germany).

In vitro scratch assay. In the present study, the wtHEK-293, p85 $/ \mathrm{p} 70^{\circ} / \mathrm{p} 60^{+} \mathrm{HEK}-293$ and p85 $/ \mathrm{p} 70^{-} /$ p60-HEK-293 cells were plated $\left(5 \times 10^{5}\right)$ in 6 -well plates and grown to $90 \%$ confluence. The confluent monolayer was scraped with $200 \mu$ l sterile pipette tips to leave a scratch. After the scratch was created, digitized images of a wound closure were taken at $0 \mathrm{~h}$ and $24 \mathrm{~h}$ with the Leica DM 1000 microscope and a digital camera. The average distance $(\mu \mathrm{m})$ between the wound edges was determined at each time point using the ImageJ software. The scratch wound assay was performed in triplicates for each cell line used in this study.

MTT assay. For the MTT assay, the wtHEK-293, p85-/p70 $/ \mathrm{p} 60^{+} \mathrm{HEK}-293$ and p85 $/ \mathrm{p} 70^{-} /$ p60-HEK-293 cells were plated in a 96-well culture plate at $5 \times 10^{5}$ per well in $100 \mu$ of DMEM supplemented with $10 \%$ FBS. The cells were incubated 
for 24, 48 and $72 \mathrm{~h}$. At each time point, $20 \mu \mathrm{l}$ of $5 \mathrm{mg} / \mathrm{ml}$ MTT (thiazolyl blue tetrazolium bromide, Sigma-Aldrich) were added to corresponding wells. After incubation with MTT for $3 \mathrm{~h}$ and removing the medium, $150 \mu \mathrm{l}$ of DMSO were added to each well and formazan crystals were dissolved. Absorbance was recorded with the microtiter plate reader, BioTek ELx800 (BioTek Instruments, Inc.), at $570 \mathrm{~nm}$. The MTT assay was carried out thrice for each cell line tested in the study.

Statistical analysis. All quantitative results are expressed as the means \pm standard deviation (SD). All experiments were performed independently and at least three times. The Student's $t$-test was used to compare mean values between experimental groups. $P<0.05, P<0.01$, and $P<0.005$ were considered to be significant.

\section{Results and Discussion}

It is generally recognized that the S6K1 gene encodes two protein isoforms (p70-S6K1 and p85S6K1) generated by alternate ATG start site utilization. In addition, a smaller and the only known splice variant of S6K1 has been reported, p31-S6K1, that is required for cellular transformation induced by the splicing factor SF2/ASF (splicing factor 2/alternative splicing factor) [7].

According to the existing data, utilization of the third alternative ATG start site in S6K1 mRNA transcript may trigger translation of additional, truncated from the N-terminus, kinase isoform - p60S6K1 [8]. Based on this assumption we hypothesized that disruption of a region located between the second and the hypothetical third ATG by the CRISPR/ Cas9 editing tool may lead to the silencing of p85/
p70-S6K1 protein expression enabling the cells to express solely p60-S6K1 [8]. Thus, we designed gRNA oligonucleotides (20 nt in size) corresponding to $106-125 \mathrm{nt}$ in the p85-S6K1 mRNA coding sequence for targeting the S6K1 gene region in human embryonic kidney cells HEK-293 (Fig. 1). The DNA vector encoding both the Cas9 endonuclease and the constructed gRNA oligonucleotide was incorporated into HEK-293. After selection individual clones were analyzed by Western blot and immunofluorescent staining using anti-S6K1 antibodies specific to its C-terminal region. According to the data of Western blot analysis, CRISPR/Cas9-mediated gene editing induced the generation of a set of clones with a different $\mathrm{S} 6 \mathrm{~K} 1$ forms expression profile (Fig. 2, A). However, among six clones selected for analysis only two (clone 2 and 6) met our expectations, since they express exclusively the p60-S6K1 isoform. The specificity of p60-S6K1 expression was further confirmed by an immunoprecipitation assay. As shown in Fig. 2, B, alternative anti-S6K1 mAbs (C3/10) specific to the S6K1 C-terminus [26] precipitated p60-S6K1 from the CRISPR/Cas9-modified $\mathrm{p} 85^{-} / \mathrm{p} 70^{-} / \mathrm{p} 60^{+} \mathrm{HEK}-293$ cells, determining the specific recognition of the p60-S6K1 isoform in the samples verified in Western blot by rabbit polyclonal anti-S6K1 antibodies.

Thus, it is the first experimental evidence confirming that the p60-S6K1 isoform is a product of alternative mRNA translation initiated from the third ATG. In favor of a given conclusion are our previous data demonstrating that inactivation of all three S6K1 translation starts, including the hypothetical third one, abolished expression of all S6K1 isoforms [23].

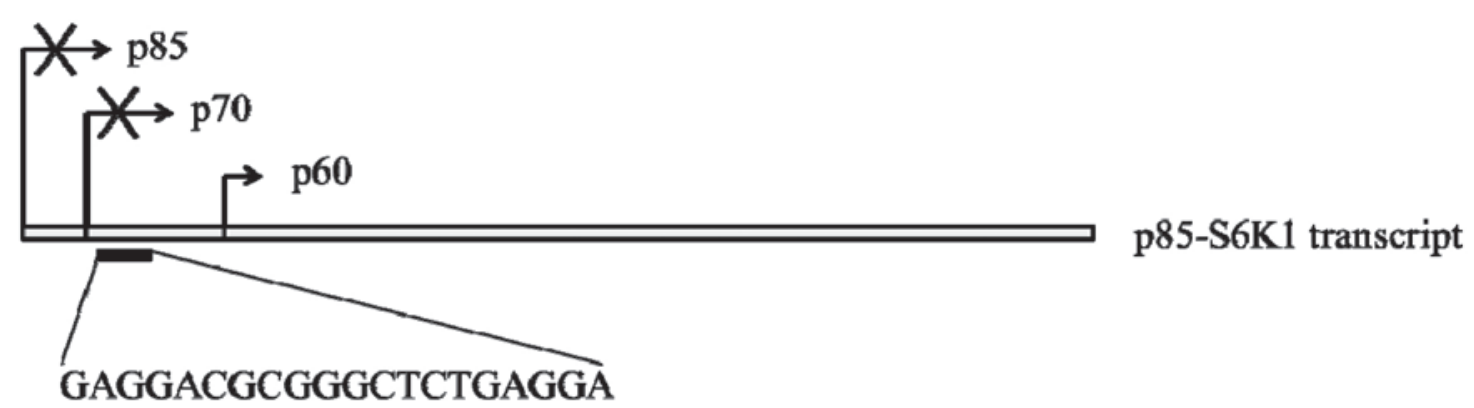

Fig. 1. A scheme of p85-S6K1 mRNA coding for p85/p70/p60-S6K1 isoforms with indication of alternative translation starts and a region that is targeted by gRNA in the S6K1 gene. Specifically designed gRNA is directed to the indicated DNA sequence to shut off the expression of both p85-S6K1 and p70-S6K1 isoforms. A black box corresponds to the approximate location of the gRNA target site (34-53 nt downstream of the second ATG site) 
A

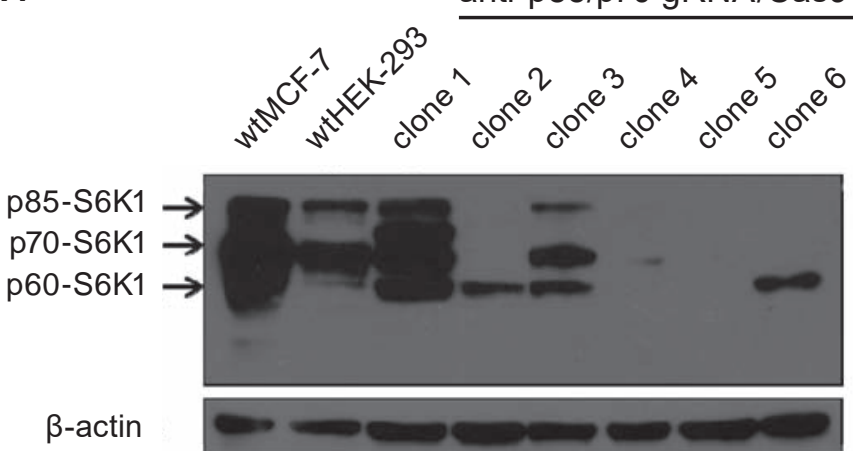

B

IP:p60-S6K1

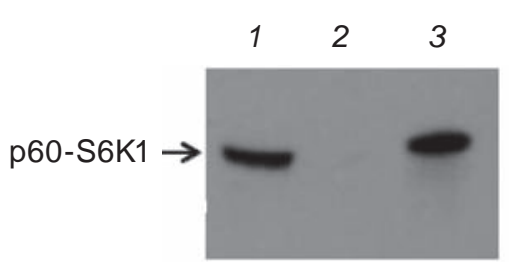

WB: S6K1

C-terminus

Fig. 2. Generation of S6K1 mutant HEK-293 cells targeted with anti-p85/p70-S6K1 gRNA/Cas9 to shut off expression of the main S6K1 isoforms, $p 85$ and $p 70$. A - Western blot analysis of the mutated HEK-293 clones after CRISPR/Cas9 application. Total cell lysates were analyzed for S6K1 expression by Western blot using anti-S6K1 polyclonal antibodies. Equal protein loading was confirmed by $\beta$-actin detection. $\boldsymbol{B}-$ Western blot analysis of p60-S6K1 immunoprecipitated from $p 85^{-} / p 70^{-} / p 60^{+} H E K-293$ cells with anti-S6K1 mAbs and blotted anti-S6K1 polyclonal antibodies. The whole-cell lysate from the $p 85 \% / p 70^{-} / p 60^{+} H E K-293$ cells was used as a control. 1 - cell lysate from $p 85^{-} / p 70^{-} / p 60^{+} H E K-293 ; 2$ - IP: flow-through; 3 - IP: anti-S6K1 mAbs (C3/10)

Apart from the clones with detected p60-S6K1 expression, clone 5 did not display the expression of any S6K1 isoform, though clone 1 expressed the $80 \mathrm{kDa}$ immunoreactive protein that does not correspond to any of known S6K1 forms. The possible explanation of such an effect of CRISPR/Cas9-mediated targeting of the S6K1 gene can be linked to the nature of the gRNA/Cas9 action. The CRISPR/Cas9 system causes the error-prone NHEJ repair to fix double-strand breaks in DNA. The indicated DNA repair system generally introduces either insertions or deletions, thus leading to unpredictable changes in a target sequence. In our case, it is possible that CRISPR/Cas9 induced specific mutagenic changes affecting in some cases the third ATG and, as a consequence, the disruption of p60-S6K1 expression or affecting mRNA splicing causing the expression of unusual $80 \mathrm{kDa}$ S6K1 forms.

Another interesting observation was that the disruption of p85/p70-S6K1 expression (Fig. 2, A, clone 2 and 6) or even their down-regulation (Fig. 2, $A$, clone 3 ) correlated with the up-regulation of p60S6K1 expression.

The generated HEK-293 clones with the disrupted expression of the S6K1 isoforms was further analyzed by the immunofluorescent detection of S6K1 with anti-S6K1 Abs. In overall, the data of immunofluorescent analysis (Fig. 3) confirmed the data of Western blot, but the detectable level of the p60S6K1 protein in the p85/p70 $/ \mathrm{p} 60^{+} \mathrm{HEK}-293$ cells was even higher than the total level of S6K1 forms in the parental HEK-293 cells that differs from the data of Western blot (Fig. 2, A). It seems that truncation of the N-terminal region may enhance recognition of the S6K1 C-terminal domain by specific antibodies which is consistent with existing data suggesting interaction of both $\mathrm{N}$ - and $\mathrm{C}$-terminal regions in the inactive S6K1 form [2].

Recently, we have reported the characterization of S6K1-deficient HEK-293 cells (p85\%/p70\% p60-HEK-293) generated by the application of the CRISPR/Cas9 technology. We have demonstrated that the disruption of S6K1 isoforms expression had no effect on phosphorylation of S6K1 substrates analyzed [23] that could be explained by the presence of the intact highly homologous S6K2 kinase that shares with S6K1 most substrates. At the same time, we found the significant inhibition of $\mathrm{p} 85^{-} / \mathrm{p} 70^{-} / \mathrm{p} 60^{-}$ HEK-293 proliferation and migration as well as the inhibition of Akt activity, based on the extent of Ser473 phosphorylation, known to be critical for cell survival and cell proliferation [23]. In the present study, analysis of p85-/p70 $/ \mathrm{p} 60^{+} \mathrm{HEK}-293$ cells revealed that selective silencing of only p85- and p70S6K1 isoforms has very similar effect. We did not find any effect on phosphorylation of some known S6K1 substrates (Fig. 4) and detected the inhibition of cell proliferation and motility (Fig. 5, 6) that accompanied reduction of Akt Ser-473 phosphorylation (Fig. 4). It should be noted that the extent of Akt phosphorylation was significantly reduced only at the condition of serum depletion. However in case 


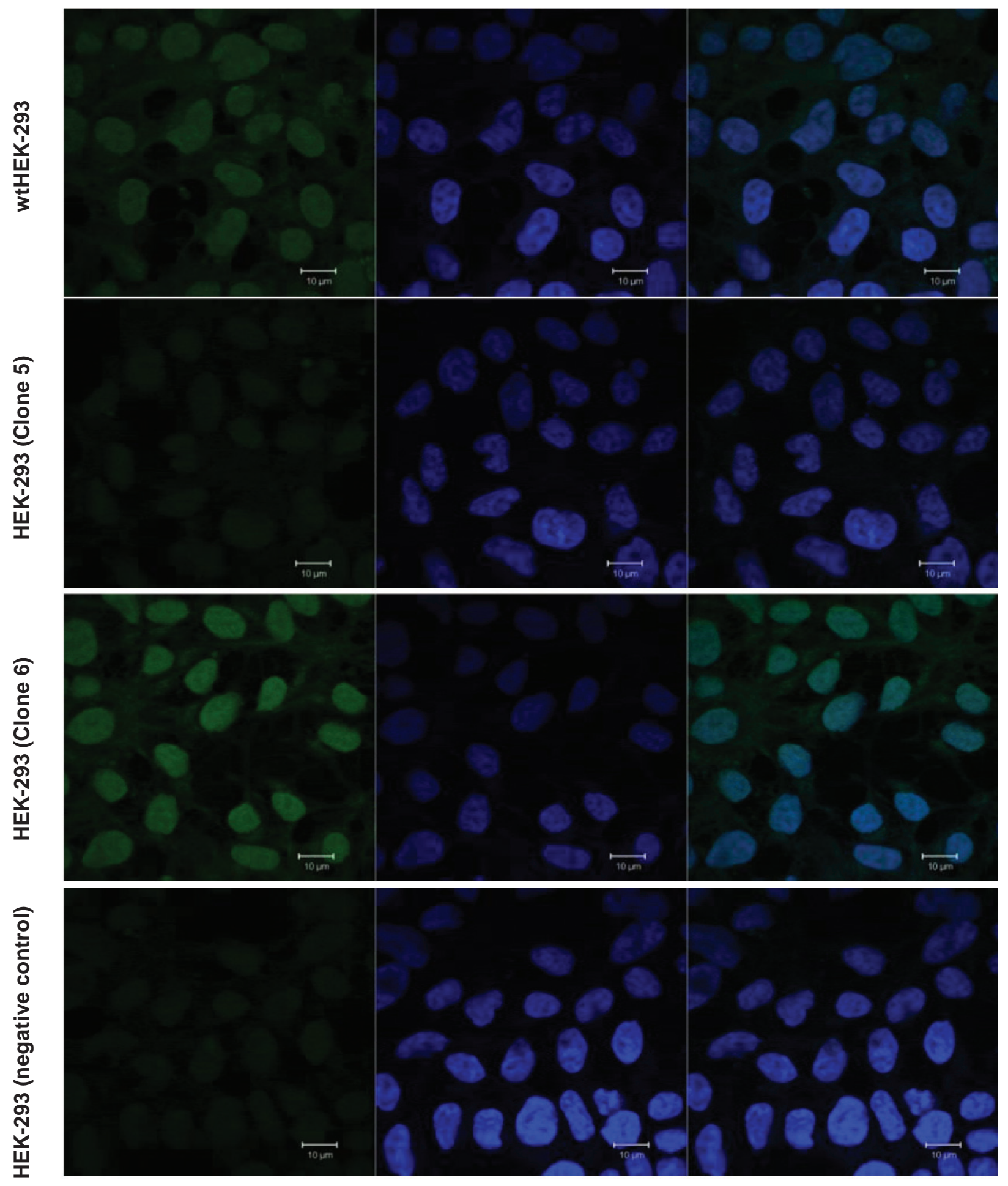

Fig. 3. Immunofluorescent analysis of $p 85 \% / p 70 / p 60^{+} H E K-293$ generated by CRISPR/Cas9 (clone 6) with the antibody specific to the S6K1 C-terminus. Wild-type HEK-293 and the generated clone 5 (knockout of the $p 85-, p 70$ - and $p 60-S 6 K 1$ protein expression) were used as a positive and negative control, respectively. Confocal images of the HEK-293 and $p 85^{\circ} / p 70^{-} / p 60^{+} H E K-293$ cells are shown 


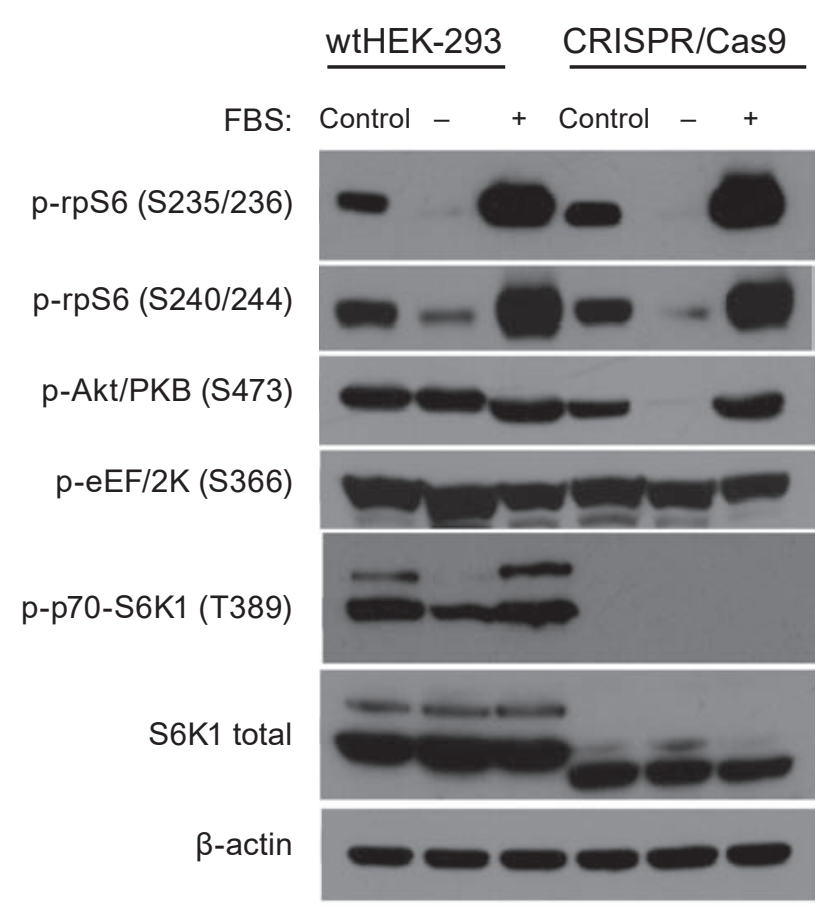

Fig. 4. Alterations in Akt/mTOR signaling under the condition of CRISPR/Cas9-mediated p85- and p70-S6K1 knockout in HEK-293 cells. The wild-type HEK-293 and $p 85 \% / p 70^{-} / p 60^{+} H E K-293$ cells were starved in serum-depleted DMEM for $24 \mathrm{~h}$ and then restimulated with 20\% FBS for 1 hour. Cell lysates were analyzed by Western blotting using the indicated antibodies. Blotting with antibodies against $\beta$-actin was used to confirm equal loading of proteins. rpS6, ribosomal protein S6; PKB, protein kinase-B; S6K1, ribosomal protein S6 kinase 1; eEF$2 K$, eukaryotic elongation factor 2 kinase; FBS, fetal bovine serum

of p85\%/p70\%/p60-HEK-293 cells Akt phosphorylation was downregulated not only in serum-starved cells, but at regular cell growth conditions as well [23].

It is a well-known fact that the activation of p85/p70-S6K1 requires mTORC1-mediated phosphorylation of Thr-412/389 [27-29]. Our investigation of Thr-412/389 phosphorylation in p60-S6K1 with the phospho-Thr412/389 specific antibodies revealed that this site remains inactive in p60-S6K1 under different growth conditions in $\mathrm{p} 85 \% \mathrm{p} 70 \%$ p60+HEK-293 (Fig. 4). These data suggest that the p60-S6K1 isoform functions differently from the p85/p70-S6K1 main isoforms and could be a subject of a different regulation mode that doesn't require mTORC1-dependent phosphorylation. Nevertheless, the ability of p60-S6K1 to be phosphorylated at Thr-412/389 in MCF-7 cells had been highlighted

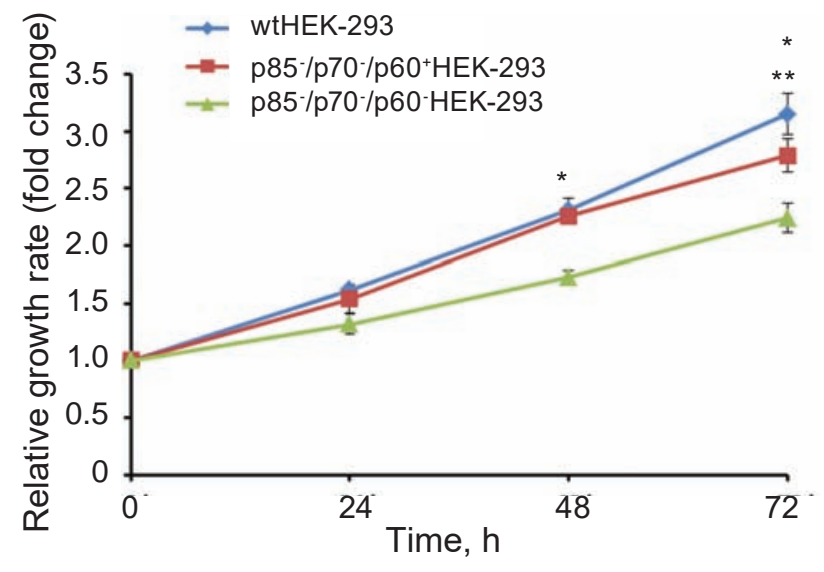

Fig. 5. HEK-293 cells expressing the sole p60-S6K1 isoform exhibit a partially restored ability to proliferate compared to S6K1 knockout HEK-293. Growth rates of the $p 85^{-} / p 70^{-} / p 60^{+} H E K-293, \quad p 85^{\circ} / p 70^{-} /$ p60-HEK-293 and wtHEK-293 cells were defined by the MTT assay. The data are the mean $\pm S D$ for three independent experiments. ${ }^{*} P<0.005, p 85 \%$ $p 70 \%$ p60-HEK-293 versus wtHEK-293 and $p 85 \%$ $p 70^{-} / p 60^{-H E K-293}$ versus $p 85^{\circ} / p 70^{-} / p 60^{+} H E K-293$; ${ }^{* * P}<0.05, \quad p 85^{-} / p 70^{-} / p 60^{+}$HEK-293 versus wtHEK-293

in [8]. Indeed, the latter result seems to be somewhat surprising taking into account that hypothetical p60S6K1 mRNA lacks an N-terminal region where the binding site for Raptor (TOS motif) is located.

The Raptor protein was determined to be a critical scaffold protein functioning within $\mathrm{mTORC1}$ [30]. In contrast to [8], our observation of the absence of Thr-412/389 phosphorylation in p60-S6K1 is completely consistent with the idea that the p60S6K1 isoform cannot be phosphorylated at this site by mTORC1 due to a lack of the TOS motif.

However, one cannot exclude other possibilities of p60-S6K1 control via phosphorylation of the Thr-412/389 site through the signaling pathway(s) distinct from mTORC1 signaling. Yet results reported in $[8,31]$ could underscore the presence of a linkage between other kinase/kinases activity and p60-S6K1 phosphorylation at Thr-412/389 in a breast carcinoma cell line MCF-7 [8]. Despite this, the HEK-293 cells used in our study seem not to involve such the kinase/kinases in p60-S6K1 regulation. In case of p60-S6K1 expressed in the p85\%/p70 $\%$ p60 ${ }^{+} \mathrm{HEK}-293$ cells, the absence of the Thr-412/389 phosphorylation event arises intriguing questions about p60-S6K1 activity. If the activity of the major $\mathrm{S} 6 \mathrm{~K} 1$ isoforms is dependent on mTORC1-mediated 
A

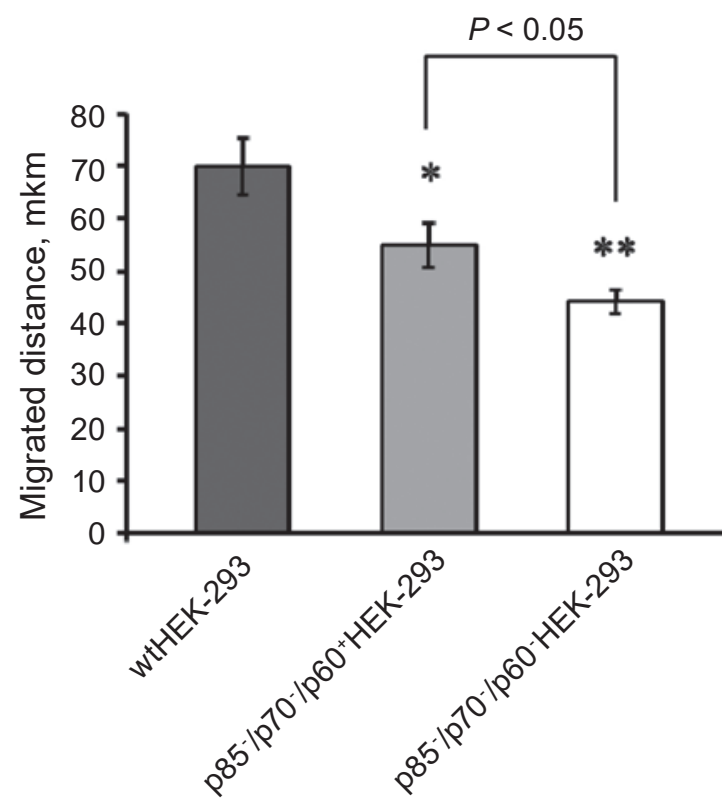

$\boldsymbol{B}$
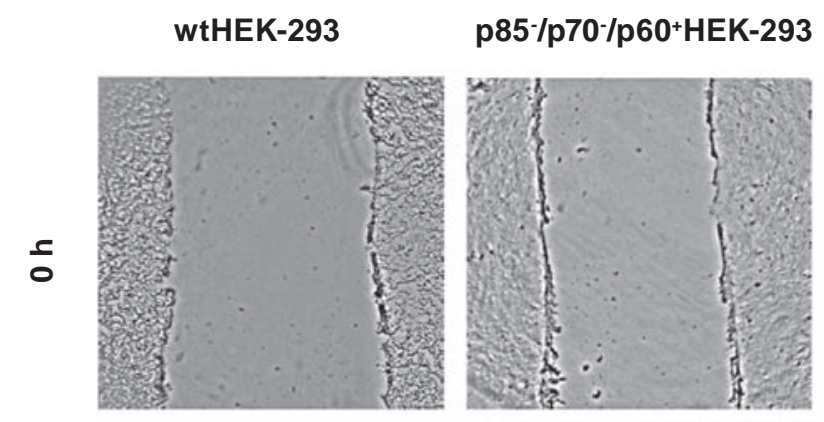

p85\%/p70//p60-HEK-293
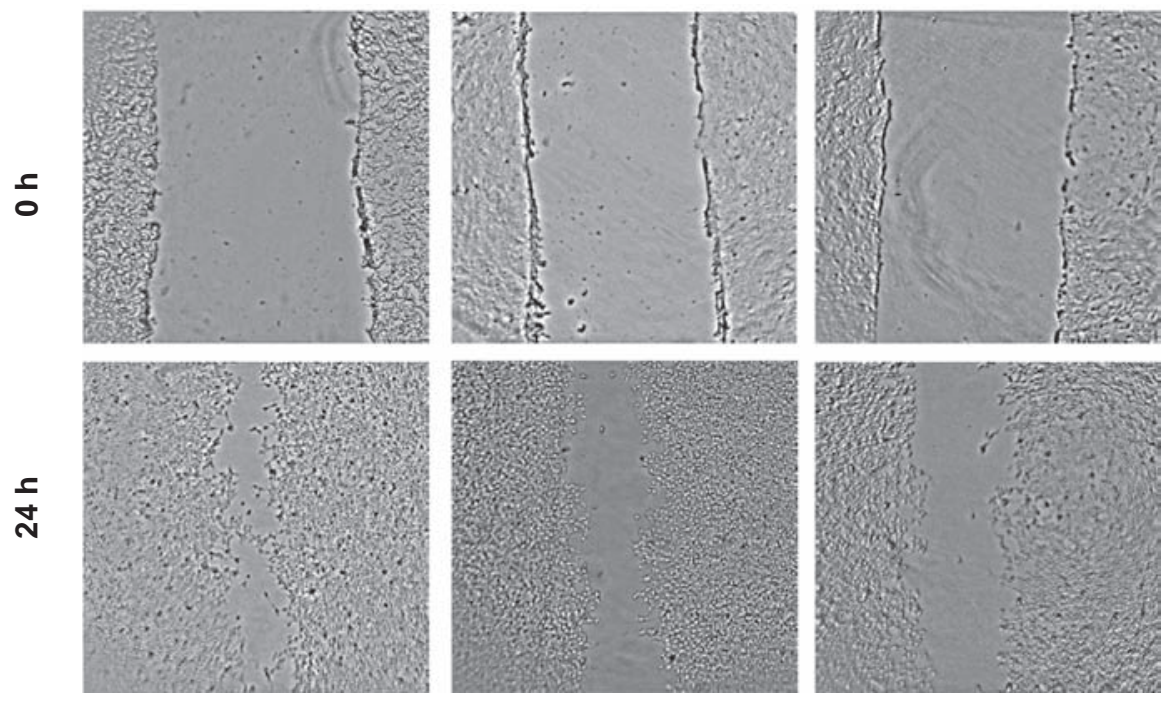

Fig. 6. Analysis of cell migration by the in vitro scratch assay reveals a partial recovery of the migration rate of HEK-293 expressing sole p60-S6K1 compared to S6K1 knockout HEK-293 cells. The confluent HEK-293, p85\% $/ p 70^{-} / p 60^{-} H E K-293$ and $p 85^{\circ} / p 70^{-} / p 60^{+} H E K-293$ cells were scratch-wounded and images were acquired 0 and 24 h post-scratching. $\boldsymbol{A}-$ Bars represent the mean \pm S.D. for three independent experiments. * $(P<0.05)$ and $* *(P<0.01)$ versus wtHEK-293. B - Representative images of a wound closure from three independent experiments are presented

phosphorylation, does the novel p60-S6K1 isoform possess kinase activity and what substrates are? Are well-known phosphorylation events common for p85- and p70-S6K1 activation except for Thr$412 / 389$ phosphorylation sufficient for the control of p60-S6K1 function? What other mechanisms of p60-S6K1 regulation could exist? These questions will be addressed in future studies.
S6K1 has been linked to the regulation of cell proliferation [32] and motility [33, 34] that are affected in transformed cells and numerous data suggest implication of S6K1 in carcinogenesis [13-21]. To evaluate the contribution of the S6K1 isoforms to the modulation of cell proliferation and cell motility we have compared the p85-/p70-/p60-HEK-293, p85\%/p70-/p60+HEK-293 and parental HEK-293 cells. 
As it has already been mentioned disruption of all three S6K1 isoforms (p85, p70, and p60) or only two of them (p85, p70) had an inhibitory effect on cell proliferation and motility, however, the extent of inhibition was not so profound in case of sustained p60-S6K1 expression. It seems that expression of p60-S6K1 to some extent rescues cells from inhibitory effect caused by the disruption of $\mathrm{p} 85$ - and/or p70-S6K1 expression.

In summary, we provide direct evidence supporting an assumption that expression of the p60S6K1 isoform is determined by mRNA translation initiated from the third alternate ATG. In addition, we conclude that a phenotype of p85\%/p70\% p60 ${ }^{+}$HEK-293 has proved to be distinct from that of the S6K1 knockout cells suggesting different functional activity of p60-S6K1 in a cell. Future research on discerning p60-S6K1 regulation and function within a cell is required and will enable us to understand a role for p60-S6K1 in cellular physiology, as well as its impact on carcinogenesis.

Acknowledgements. This work was supported in part by a fellowship from Boehringer Ingelheim Fonds (BIF) awarded to Igor Zaiets.

\section{IЗОФОРМА КІНАЗИ 1 РИБОСОМНОГО ПРОТЁ̈НУ S6, P60-S6K1, С ПРОДУКТОМ АЛЬТЕРНАТИВНОЇ ТРАНСЛЯЦІї мРНК}

\section{I. В. Заєиь, А. С. Сівченко, А. I. Хоруженко, Л. О. Савінська, В. В. Філоненко}

Інститут молекулярної біології і генетики НАН України, Київ; e-mail: filonenko@imbg.org.ua

S6 кіназа 1 (S6K1) є відомим ефектором mTORC1 (mechanistic target of rapamycin complex 1), що бере участь, головним чином, у регуляції клітинного росту та метаболізму. Порушення регуляції mTOR/S6K1-залежного сигналювання супроводжують розвиток численних патологій в людини, включаючи онкологічні, нейродегенеративні та серцево-судинні захворювання, а також метаболічні розлади. Дані, що $є$ в літературі, надають підстави вважати, що ген S6K1 кодує декілька протеїнових ізоформ кінази, а саме p85-S6K1, p70-S6K1 і p60S6K1. На сьогодні найдетальніше досліджено p85-S6K1 та p70-S6K1 ізоформи кінази. Похо- дження та функціональне значення ізоформи p60-S6K1 залишається незрозумілим, проте існує припущення, що вона може бути продуктом альтернативної трансляції S6K1 мРНК. У даній роботі наведено дані про створення клітинної лінії НЕK-293, в якій відбувається експресія виключно p60-S6K1 внаслідок CRISPR/Cas9-опосредкованої інактивації трансляції протеїнів p85- та p70-S6K1. Більш того, в одержаних модифікованих клітинах виявлено підвищений рівень експресії p60-S6K1 порівняно 3 вихідними клітинами HEK-293. Наші дані підтверджують припущення, що р60S6K1 утворюється внаслідок альтернативної трансляції мРНК, швидше за все, спільного для p85- та p70-S6K1 транскрипту і вказують на зв'язок між еспресією р60-S6K1 і такими процесами, як клітинна проліферація та рухливість. Крім того, згідно 3 представленими даними ізоформа p60-S6K1 може піддаватися окремому способу регуляції порівняно з p70-S6K1, про що свідчить відсутність mTOR-залежного фосфорилування p60-S6K1 за T389, що є важливим для активації кінази.

К л юч о в $\quad$ с ло ва: CRISPR/Cas9 технологія, p60-S6 кіназа 1 (p60-S6K1), Akt/ mTOR/S6K1-сигнальний шлях.

\section{ИЗОФОРМА КИНАЗЫ 1 РИБОСОМНОГО ПРОТЕИНА S6, Р60-S6К1, ЯВЛЯЕТСЯ ПРОДУКТОМ АЛЬТЕРНАТИВНОЙ ТРАНСЛЯЦИИ MPHK}

И. В. Заеи, А. С. Сивченко, А. И. Хоруженко, Л. А. Савинская, В. В. Филоненко

Институт молекулярной биологии
и генетики НАН Украины, Киев;
e-mail: filonenko@imbg.org.ua

S6 киназа 1 (S6K1) является известным эффектором mTORC1 (mechanistic target of rapamycin complex 1), участвующим, главным образом, в регуляции клеточного роста и метаболизма. Нарушения в регуляции $\mathrm{mTOR} /$ S6K1-зависимого сигналинга способствуют развитию многочисленных патологий у человека, включая онкологические, нейродегенеративные и сердечно-сосудистые заболевания, а также метаболические расстройства. Существующие данные дают основания полагать, что ген S6K1 
кодирует несколько протеиновых изоформ киназы, включая p85-S6K1, p70-S6K1 и p60-S6K1. На сегодняшний день наиболее изученными являются изоформы p85-S6K1 и p70-S6K1. Происхождение и функциональное значение изоформы p60-S6K1 остаётся непонятным, однако существует предположение, что она может быть продуктом альтернативной трансляции мРНК. В работе представлены данные о создании клеточной линии НЕК-293, в которой экспрессируется исключительно p60-S6K1 вследствие CRISPR/ Cas9-опосредованной инактивации трансляции протеинов p85- и p70-S6K1. Более того, в созданных модифицированных клетках выявлен повышенный уровень экспрессии р60-S6K1 по сравнению с исходными клетками НЕК-293. Наши результаты подтверждают предположение, что изоформа p60-S6K1 образовывается в результате альтернативной трансляции, скорее всего, общего для p85- и p70-S6K1 транскрипта и раскрывают связь между экспрессией р60S6K1 и такими процессами, как клеточная пролиферация и подвижность. Кроме того, наши данные указывают на то, что изоформа р60S6K1 может подвергаться отдельному способу регулирования по сравнению с p70-S6K1, о чем свидетельствует отсутствие mTOR-зависимого фосфорилирования p60-S6K1 по Т389, важного для активации киназы.

К л юч в в е с ло в а: CRISPR/Cas9 технология, p60-S6 киназа 1 (p60-S6K1), Akt/mTOR/ S6K1-сигнальный путь.

\section{References}

1. Dann SG, Selvaraj A, Thomas G. mTOR Complex1-S6K1 signaling: at the crossroads of obesity, diabetes and cancer. Trends Mol Med. 2007; 13(6): 252-259.

2. Magnuson B, Ekim B, Fingar DC. Regulation and function of ribosomal protein S6 kinase (S6K) within mTOR signalling networks. Biochem J. 2012; 441(1): 1-21.

3. Zoncu R, Efeyan A, Sabatini DM. mTOR: from growth signal integration to cancer, diabetes and ageing. Nat Rev Mol Cell Biol. 2011; 12(1): 21-35.

4. Wullschleger S, Loewith R, Hall MN. TOR signaling in growth and metabolism. Cell. 2006; 124(3): 471-484.

5. Fenton TR, Gout IT. Functions and regulation of the $70 \mathrm{kDa}$ ribosomal S6 kinases. Int J Biochem Cell Biol. 2011; 43(1): 47-59.
6. Grove JR, Banerjee P, Balasubramanyam A, Coffer PJ, Price DJ, Avruch J, Woodgett JR. Cloning and expression of two human p70 S6 kinase polypeptides differing only at their amino termini. Mol Cell Biol. 1991; 11(11): 5541-5550.

7. Karni R, de Stanchina E, Lowe SW, Sinha R, $\mathrm{Mu} \mathrm{D}$, Krainer AR. The gene encoding the splicing factor SF2/ASF is a proto-oncogene. Nat Struct Mol Biol. 2007; 14(3): 185-193.

8. Kim D, Akcakanat A, Singh G, Sharma C, Meric-Bernstam F. Regulation and localization of ribosomal protein S6 kinase 1 isoforms. Growth Factors. 2009; 27(1): 12-21.

9. Cheatham L, Monfar M, Chou MM, Blenis J. Structural and functional analysis of pp70S6k. Proc Natl Acad Sci USA. 1995; 92(25): 1169611700.

10. Mahalingam M, Templeton DJ. Constitutive activation of S6 kinase by deletion of aminoterminal autoinhibitory and rapamycin sensitivity domains. Mol Cell Biol. 1996; 16(1): 405-413.

11. Schalm SS, Blenis J. Identification of a conserved motif required for mTOR signaling. Curr Biol. 2002; 12(8): 632-639.

12. Panasyuk G, Nemazanyy I, Zhyvoloup A, Bretner M, Litchfield DW, Filonenko V, Gout IT. Nuclear export of S6K1 II is regulated by protein kinase CK2 phosphorylation at Ser-17. J Biol Chem. 2006; 281(42): 31188-31201.

13. Bärlund M, Monni O, Kononen J, Cornelison R, Torhorst J, Sauter G, Kallioniemi OLLI-P, Kallioniemi A. Multiple genes at 17q23 undergo amplification and overexpression in breast cancer. Cancer Res. 2000; 60(19): 5340-5344.

14. van der Hage JA, van den Broek LJ, Legrand C, Clahsen PC, Bosch CJ, Robanus-Maandag EC, van de Velde CJ, van de Vijver MJ. Overexpression of P70 S6 kinase protein is associated with increased risk of locoregional recurrence in node-negative premenopausal early breast cancer patients. Br J Cancer. 2004; 90(8): 1543-1550.

15. Bostner J, Karlsson E, Eding CB, PerezTenorio G, Franzén H, Konstantinell A, Fornander T, Nordenskjöld B, Stål O. S6 kinase signaling: tamoxifen response and prognostic indication in two breast cancer cohorts. Endocr Relat Cancer. 2015; 22(3): 331-343.

16. Kremer CL, Klein RR, Mendelson J, Browne W, Samadzedeh LK, Vanpatten K, Highstrom L, 
Pestano GA, Nagle RB. Expression of mTOR signaling pathway markers in prostate cancer progression. Prostate. 2006; 66(11): 1203-1212.

17. Yoshida S, Matsumoto K, Arao T, Taniguchi H, Goto I, Hanafusa T, Nishio K, Yamada Y. Gene amplification of ribosomal protein S6 kinase-1 and -2 in gastric cancer. Anticancer Res. 2013; 33(2): 469-475.

18. Li PD, Zhang WJ, Zhang MY, Yuan LJ, Cha YL, Ying XF, Wu G, Wang HY. Overexpression of RPS6KB1 predicts worse prognosis in primary HCC patients. Med Oncol. 2012; 29(5): 30703076.

19. Ismail HM. Overexpression of s6 kinase 1 in brain tumours is associated with induction of hypoxia-responsive genes and predicts patients' survival. J Oncol. 2012; 2012: 416927.

20. Lyzogubov V, Khozhaenko Y, Usenko V, Antonjuk S, Ovcharenko G, Tikhonkova I, Filonenko V. Immunohistochemical analysis of Ki-67, PCNA and S6K1/2 expression in human breast cancer. Exp Oncol. 2005; 27(2): 141-144.

21. Filonenko VV, Tytarenko R, Azatjan SK, Savinska LO, Gaydar YA, Gout IT, Usenko VS, Lyzogubov VV. Immunohistochemical analysis of S6K1 and S6K2 localization in human breast tumors. Exp Oncol. 2004; 26(4): 294-299.

22. Pérez-Tenorio G, Karlsson E, Waltersson MA, Olsson B, Holmlund B, Nordenskjöld B, Fornander T, Skoog L, Stål O. Clinical potential of the mTOR targets S6K1 and S6K2 in breast cancer. Breast Cancer Res Treat. 2011; 128(3): 713-723.

23. Zaiets IV, Sivchenko AS, Khoruzhenko AI, Filonenko VV. Generation of HEK-293 stable cell lines with disrupted expression of ribosomal protein S6 kinase (S6K1) isoforms using the CRISPR/Cas9 genome editing system. Biopolym Cell. 2017; 33(5): 356-366.

24. Hsu PD, Scott DA, Weinstein JA, Ran FA, Konermann S, Agarwala V, Li Y, Fine EJ, Wu X, Shalem O, Cradick TJ, Marraffini LA, Bao G, Zhang F. DNA targeting specificity of RNA-guided Cas9 nucleases. Nat Biotechnol. 2013; 31(9): 827-832.

25. Savinska LO, Kijamova RG, Pogrebnoy PV, Ovcharenko GV, Gout IT, Filonenko VV. Comparative characterization of S6 kinase $\alpha$ and $\beta$ isoforms expression in mammalian tissues. Biopolym Cell. 2001; 17(5): 374-379.
26. Pogrebnoy PV, Kukharenko AP, Tykhonkova IA, Pal'chevskiy SS, Savinskaya LA, Pogrebnaya AP, Valevka TI, Markeeva NV, Soldatkina MA, Matsuka GK, Gout IT, Filonenko VV. Generation and characterization of monoclonal antibodies to p70S6kinase $\alpha$. Exp Oncol. 1999; 21(3-4): 232-238.

27. Isotani $S$, Hara $K$, Tokunaga $C$, Inoue $H$, Avruch J, Yonezawa K. Immunopurified mammalian target of rapamycin phosphorylates and activates p70 S6 kinase alpha in vitro. $J$ Biol Chem. 1999; 274(48): 34493-34498.

28. Burnett PE, Barrow RK, Cohen NA, Snyder SH, Sabatini DM. RAFT1 phosphorylation of the translational regulators p70 S6 kinase and 4EBP1. Proc Natl Acad Sci USA. 1998; 95(4): 14321437.

29. Weng QP, Kozlowski M, Belham C, Zhang A, Comb MJ, Avruch J. Regulation of the p70 S6 kinase by phosphorylation in vivo. Analysis using site-specific anti-phosphopeptide antibodies. $J$ Biol Chem. 1998; 273(26): 16621-16629.

30. Hara K, Maruki Y, Long X, Yoshino K, Oshiro N, Hidayat S, Tokunaga C, Avruch J, Yonezawa K. Raptor, a binding partner of target of rapamycin (TOR), mediates TOR action. Cell. 2002; 110(2): 177-189.

31. Dennis PB, Pullen N, Kozma SC, Thomas G. The principal rapamycin-sensitive p70(s6k) phosphorylation sites, T-229 and T-389, are differentially regulated by rapamycin-insensitive kinase kinases. Mol Cell Biol. 1996; 16(11): 6242-6251.

32. Fingar DC, Richardson CJ, Tee AR, Cheatham L, Tsou C, Blenis J. mTOR controls cell cycle progression through its cell growth effectors S6K1 and 4E-BP1/eukaryotic translation initiation factor 4E. Mol Cell Biol. 2004; 24(1): 200-116.

33. Chiang GG, Abraham RT. Phosphorylation of mammalian target of rapamycin (mTOR) at Ser2448 is mediated by p70S6 kinase. J Biol Chem. 2005; 280(27): 25485-25490.

34. Liu L, Li F, Cardelli JA, Martin KA, Blenis J, Huang S. Rapamycin inhibits cell motility by suppression of mTOR-mediated S6K1 and 4EBP1 pathways. Oncogene. 2006; 25(53): 70297040 .

Received 13.04.2018 